L. CAO, Z. LIN, F. PENG, W. WANG, R. HUANG, C. WANG,* J. YAN, J. LIANG, Z. ZHANG, T. ZHANG, L. LONG, J. SUN,* W. LIN* (PEKING UNIVERSITY, BEIJING AND XIAMEN

UNIVERSITY, P. R. OF CHINA; UNIVERSITY OF CHICAGO, USA; STOCKHOLM UNIVERSITY, SWEDEN)

Self-Supporting Metal-Organic Layers as Single-Site Solid Catalysts Angew. Chem. Int. Ed. 2016, 55, 4962-4966.

\section{Hydrosilylations Catalyzed by Iron-Doped Metal-Organic Layers}

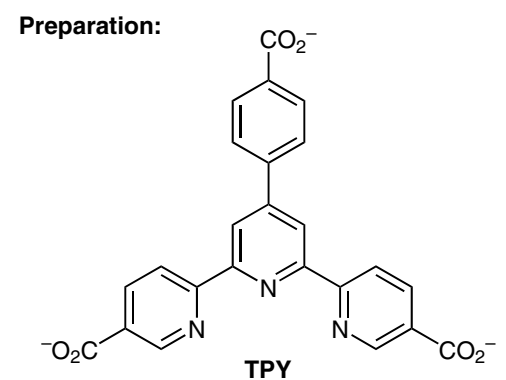<smiles>O=C([O-])c1ccc(-c2cc(-c3ccc(C(=O)[O-])cc3)cc(-c3ccc([N+](=O)[O-])cc3)c2)cc1</smiles>

BTB

Gategory

Polymer-Supported

Synthesis

Key words

metal-organic layers

heterogeneous catalysis

hafnium

iron

hydrosilylation

alkenes

Examples:

$\mathrm{Ph}+$<smiles>[SiH3]c1ccccc1</smiles>

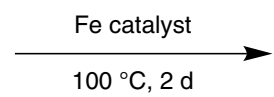<smiles>c1ccc(CC[SiH2]c2ccccc2)cc1</smiles>

2 Fe-TPY-MOL
3 (linear)

Catalyst

Fe-TPY-MOL (0.02 mol\%): Fe-TPY-MOF1 (0.02 mol\%) Fe-TPY-MOF2 (0.02 mol\%):

homogeneous Fe-TPY (0.2 mol\%):<smiles>CC([SiH2]c1ccccc1)c1ccccc1</smiles>

Yield (\%)

$100 / 0$

$0 / 0 \quad(6 d)$

$30 / 0$

$3 / 43$
Significance: Metal-organic layers (MOLs) composed of $\left[\mathrm{Hf}_{6} \mathrm{O}_{4}(\mathrm{OH})_{4}\left(\mathrm{HCO}_{2}\right)_{6}\right]$ secondary building units and 4,4',4"-benzene-1,3,5-triyltribenzoate (BTB) bridging ligands were prepared. The MOL structures were doped with 4'-(4-carboxylatophenyl)-2,2':6',2"'-terpyridine-5,5"-dicarboxylate (TPY) and $\mathrm{FeBr}_{2}$ to afford the solid material Fe-TPY-MOL, which catalyzed the hydrosilylation of terminal olefins. For example, the reaction of styrene (1) with phenylsilane (2) proceeded in the presence of Fe-TPY-MOL to give the linear silane $\mathbf{3}$ in quantitative yield.
Comment: In the reaction of styrene (1) with phenylsilane (2), the Fe-TPY-MOL catalyst showed a better performance than the metal-organic framework-based catalysts Fe-TPY-MOF1 (prepared from an interlocked Hf-MOF instead of the MOLs), Fe-TPY-MOF2 (prepared from a stacked Hf-MOF instead of the MOLs), or the homogeneous counterpart Fe-TPY (prepared from $\mathrm{FeBr}_{2}$, TPY, and $\mathrm{NaBHEt}_{3}$ ). When Fe-TPY-MOF1, Fe-TPY-MOF2, and Fe-TPY were employed as catalysts for the reaction, the ratios of products $\mathbf{3}$ and $\mathbf{4}$ were 0:0, $30: 0$, and 3:43, respectively. 